\title{
Paideusis
}

\section{Total Form as a Moveable Feast: A Response to Walsh}

\section{Dianne Bogdan}

Volume 3, Number 2, 1990

URI: https://id.erudit.org/iderudit/1073400ar

DOI: https://doi.org/10.7202/1073400ar

See table of contents

Publisher(s)

Canadian Philosophy of Education Society

ISSN

0838-4517 (print)

1916-0348 (digital)

Explore this journal

Cite this article

Bogdan, D. (1990). Total Form as a Moveable Feast: A Response to Walsh.

Paideusis, 3(2), 43-44. https://doi.org/10.7202/1073400ar

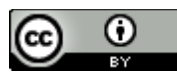

This document is protected by copyright law. Use of the services of Erudit (including reproduction) is subject to its terms and conditions, which can be viewed online.

https://apropos.erudit.org/en/users/policy-on-use/
This article is disseminated and preserved by Érudit.

Érudit is a non-profit inter-university consortium of the Université de Montréal, Université Laval, and the Université du Québec à Montréal. Its mission is to promote and disseminate research.

https://www.erudit.org/en/ 


\section{Total Form as a Moveable Feast}

\section{A Response to Walsh}

\section{Dianne Bogdan, Ontario Institute for Studies in Education}

I am grateful to Jill Paton Walsh for her close reading of my taxonomy of literary responses. She is, as one would expect, interested in reader response from the vantage point of the writer who, she avers, is preoccupied in the very act of creation with orchestrating the responses of the reader. Walsh's conception of the literary encounter is based on a kind of perfect match between authorial intention and the lived experience of the reader. It is in the possibility of just such a utopian event (which undergirds the notion of stasis) that lies the answer to Walsh's question about where the responses of the taxonomy are located. The responses cited in my article are not, as Walsh speculated, essay answers, but real classroom responses from real readers. Yet, it is understandable that they come across as "textoids";: that is, as interpretations or attempts at interpretations devoid of social context, for, conceptually, the hierarchical array of "better" and "worse" responses (stock, kinetic, and so on) of the taxonomy is not grounded in the "lived-through experience" 2 of the work by an embodied reader, but rather is contingent upon the ontological construct of literature as an "order of words." 3 Within the stucturalist configuration of the taxonomy, the responses do not reside in the readers who make them but in the hypothetical reality of a "full literary response" as the possibility of "total form" "4 realized by either stasis or dialectic. But, most real responses--imperfect admixtures of "real" and "literary" experience within a specific individual consciousness and/or social context, under the rubric of the taxonomy, must be consigned to the twilight zone of partial form. The conception of total form as a "moveable feast" attempts to mitigate the anomalies of the distinction between total and partial form.

Since drafting the taxonomy, I have dismantled and reassembled it as a moveable feast ${ }^{5}$ in an attempt to apply it to a number of issues I think are important for the philosophy of literature and literature education. I believe that the original conceptualization is useful as an illustration of a thorough-going structuralist theory of literary interpretation in showing the relationship between aesthetic pleasure and critical perception. However, I have recently been more interested in the phenomenology of literary reading in terms of the moral import of what Sir Philip Sidney called its "moving power,"6 on the presupposition that literature becomes a tool of critical consciousness because literary reading realizes things in readers: literature acts on readers, who then act on the world. For those who may be interested in pursuing this topic further, I would refer them to the three major revisions of the taxonomy since it was first published in Paideusis in 1987. For its implications for feminist criticism, multicultural education, and questions of canon and curricular choice, see "A Case Study of the Selection/Censorship Problem and the Educational Value of Literature," Journal of Education, 170(2), 1988, 39-57; for its implications for the relationship between aesthetic experience and worldview within the parameters of poststructuralist literary theory, see chapters 5, 6, and 7 in Deanne Bogdan and Stanley B. Straw (eds.), Beyond Communication: Reading Comprehension and Criticism (Portsmouth, NH: Boynton/Cook-Heinemann, 1990), pp. 109-195; and 
for the reversal of the logical priority of the critical response over the direct, participating response, see "The Re-Educated Imagination and he Power of Literary Engagement," Special Issue, Proceedings of the Embattled Books Conference, University of Calgary, March 22-24, 1990, Journal of Educational Thought (in press).

\section{Notes}

${ }^{1}$ Russell A. Hunt and Douglas Vipond, "Aesthetic Reading: Some Strategies for Research," English Quarterly 20(3), (Fall)1987), 117.

${ }^{2}$ Louise M. Rosenblatt, The Reader, the Text, the Poem: The Transactional Theory of the Literary Work (Carbondale, Illinois: Southem Illinois University Press), 26.

${ }^{3}$ Northrop Frye, Anatomy of Criticism: Four Essays (Princeton: Princeton University Press, 1957), 17, 121.

${ }^{4}$ Ibid., 115.

${ }^{5}$ See Deanne Bogdan, "Reclaiming Total Form: Reading and the 'Fate of Beauty"', in Deanne Bogdan and Stanley B. Straw, (eds.), Beyond Communication: Reading Comprehension and Criticism (Portsmouth, NH: Boynton/CookHeinemann, 1990), 183ff.

${ }^{6}$ See Sir Philip Sidney, A Defence of Poetry, ed. J.A. Van Dorsten (London: Oxford University Press), 1966. 